\title{
Overdiagnosis of a typical carcinoid tumor as an adenocarcinoma of the lung: a case report and review of the literature
}

\author{
Ilhan Demirci ${ }^{1 *}$, Susanne Herold ${ }^{2}$, Andreas Kopp ${ }^{3}$, Michael Flaßhove ${ }^{4}$, Bernd Klosterhalfen ${ }^{5}$ and Hermann Janßen ${ }^{1}$
}

\begin{abstract}
Background: Overdiagnosis of bronchopulmonary carcinoid tumors together with overtreatment can cause serious postoperative consequences for the patient. We report of a patient with a typical bronchopulmonary carcinoid tumor, which was initially misdiagnosed and treated as an adenocarcinoma of the lung. GnrH receptors and the associated Raf-1/MEK/ERK-1/2-pathway are potential targets for analogs in cancer treatment. We suspected a correlation between the lack of tumor growth, application of leuprolide and the Raf-1/MEK/ERK-1/2-pathway. Therefore, we examined $\mathrm{GnrH}$ receptor status in the examined specimen.

Case presentation: In 2010 a 77 year-old male patient was shown to have a tumor mass of about $1.7 \mathrm{~cm}$ diameter in the inferior lobe of the left lung. Since 2005, this tumor had hitherto been known and showed no progression in size. The patient suffered from prostate cancer 4 years ago and was treated with TUR-P, radiation therapy and the application of leuprolide. We conducted an explorative thoracotomy with atypical segment resection. The first histological diagnosis was a metastasis of prostate cancer with lymphangiosis carcinomatosa. After several immunohistochemical stainings, the diagnosis was changed to adenocarcinoma of the lung. We conducted a re-thoracotomy with lobectomy and systematic lymphadenectomy 12 days later. The tumor stage was PT1 NO MX G2 L1 V0 RO. Further immunohistochemical studies were performed. We received the results 15 days after the last operation. The diagnosis was ultimately changed to typical carcinoid tumor without any signs of lymphatic vessel invasion. The patient recovered well from surgery, but still suffers from dyspnea and lack of physical performance. Lung function testing revealed no evidence of impairment.

Conclusion: The use of several immunohistochemical markers, careful evaluation of hematoxylin-eosin sections and the Ki-67 labelling index are important tools in discriminating between carcinoids and other bronchopulmonary carcinomas. Although we could not detect GnrH-receptors in the examined specimen, there may be individual differences in expression. GnrH receptor profiles in typical and atypical carcinoids should be scrutinized. This could lead to new therapeutical options, since the $\mathrm{GnrH}$ receptor has already been described on atypical carcinoids. Clinically tested drugs such as leuprolide could come to use.
\end{abstract}

Keywords: Overdiagnosis, typical carcinoid tumors, atypical carcinoid tumors, leuprolide, GnrH receptor, Raf-1/MEK ERK-1/2-pathway

\footnotetext{
* Correspondence: Ilhan.Demirci@Krankenhaus-Dueren.de

'Department of General, Visceral, Vascular and Thoracic Surgery, Hospital of

Düren

Full list of author information is available at the end of the article
} 


\section{Background}

Laennec was the first one to report on an intrabronchial tumor mass, published posthumously in 1881. This was the first description of a bronchial carcinoid tumor [1]. The first detailed description of a so-called bronchial adenoma, which was probably a carcinoid tumor too, was adduced by Mueller in 1882 [2]. The term "Karzinoid" was introduced by the German pathologist Oberndorfer in 1907 for tumors of the ileum, although Lubarsch had described a similar case of two patients with ileal carcinoid tumors in $1888[3,4]$. Carcinoids represent approximately $2 \%$ of all lung tumors. $25-30 \%$ of all neuroendocrine tumors appear in the bronchopulmonary system. The age-adjusted incidence rates of bronchopulmonary carcinoids and neuroendocrine tumors in general have increased over the last 30 years for all genders and races. This increase may be due to improvements in histopathological diagnosis and classification and to the more frequent use of endoscopic procedures [5-7]. The average age of diagnosis is at 60 years. Modlin et al. and others described a female predominance $[8,9]$, whereas Quaedvlieg et al. described a female predominance only for patients under the age of 50 years, suggesting hormonal influence [10]. Typical carcinoids are the most common lung tumors in children. Misdiagnosis of typical carcinoid tumors of the lung as SCLC has been reported previously [11,12]. We report of a patient with a typical bronchopulmonary carcinoid tumor, which was initially misdiagnosed as an adenocarcinoma of the lung and also treated as such.
This led to serious postoperative consequences for the patient. The tumor described in our case report showed almost no progression in 5 years. GnrH receptors and the associated Raf-1/MEK/ERK-1/2-pathway are potential targets for analogs in cancer treatment. We suspected a correlation between the lack of tumor growth, application of leuprolide and the Raf-1/MEK/ERK-1/2pathway. Therefore, we examined $\mathrm{GnrH}$ receptor status in the examined specimen.

\section{Case report}

In March 2010 a 77 year-old male patient was shown to have a tumor mass of about $1.7 \mathrm{~cm}$ diameter in the inferior lobe of the left lung (see Figure 1). Since 2005, this asymptomatic tumor mass had hitherto been known with a diameter of approximately $1.7 \mathrm{~cm}$. It showed almost no increase in size and could therefore be classified as "stable disease". The patient suffered from prostate cancer 4 years ago and was treated with TUR-P, radiation therapy and the application of leuprolide. Other pre-existing conditions were arterial hypertension and chronic obstructive lung disease. The physical examination was without pathological findings. A preoperative PET/CT scan was not performed due to the fact that neither a positive nor a negative PET/CT scan result rules out a surgical intervention. Therefore, we conducted a left anterolateral thoracotomy with atypical segment resection for curative tumor treatment. The pathological examination of the resected tissue revealed a malignant tumor with a diameter of $1.5 \mathrm{~cm}$. As a first

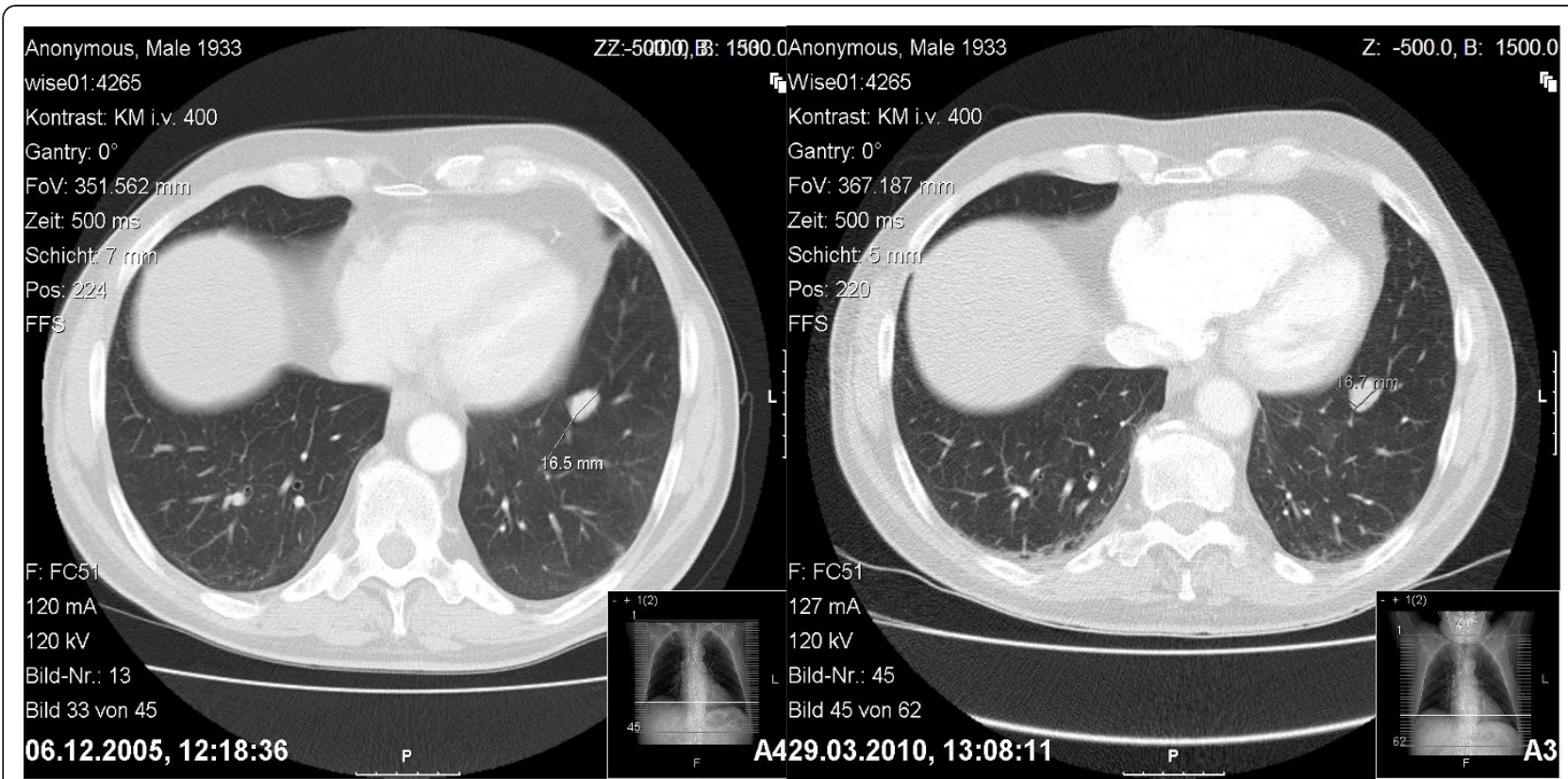

Figure 1 Transversal CT scans of the thorax from the years 2005 (left) and 2010 (right), showing a solid tumor mass in the left inferior lobe of the lung with almost no progress in size. The tumor had a diameter of approximately $1.7 \mathrm{~cm}$ in both 2005 and 2010. 
histological diagnosis, a metastasis of prostate cancer with lymphangiosis carcinomatosa was assumed. Further immunohistochemical studies for PSA, CK7, CK20 and TTF1 were performed. Stainings for PSA and CK20 were both negative, stainings for TTF1 showed a strong nuclear and for CK7 a strong cytoplasmatic reaction (see Figure 2). Therefore, the initial diagnosis of a metastasis of prostate cancer was changed to adenocarcinoma of the lung. Relying on this new diagnosis, we conducted a re-thoracotomy with lobectomy and systematic lymphadenectomy as an adequate treatment 12 days after the above-mentioned operation. The resection margins were free of tumor cells. To this point, the tumor stage was pT1 N0 MX G2 L1 V0. Further immunohistochemical studies were performed. These revealed cytoplasmatic expression of chromogranin A and synaptophysin, plasma membrane associated expression of CD56 and a Ki-67 labelling index of approximately 5\% (see Figure 2). After re-evaluation of all results and particularly with regard to the little progress in tumor size, the diagnosis was ultimately changed to typical bronchopulmonary carcinoid tumor. A re-examination of the sample showed no invasion of tumor cells in lymphatic vessels. The patient recovered well from surgery and received postoperative rehabilitation therapy. In addition lung function testing revealed no evidence of impairment. Follow-up care is carried out by our department of oncology. The typical carcinoid tumor described in our case report showed almost no progression in 5 years. We suspected a correlation between the lack of tumor growth, application of leuprolide and the Raf-1/ MEK/ERK-1/2-pathway. Therefore, we examined GnrH receptor status in the examined specimen. An expression of $\mathrm{GnrH}$ receptor could not be detected.

\section{Discussion}

It is generally assumed that carcinoids arise from Kulchitsky cells disseminated in the bronchopulmonary mucosa [13]. Typical carcinoids (TCs) are usually welldifferentiated tumors of histologically ordered structure,

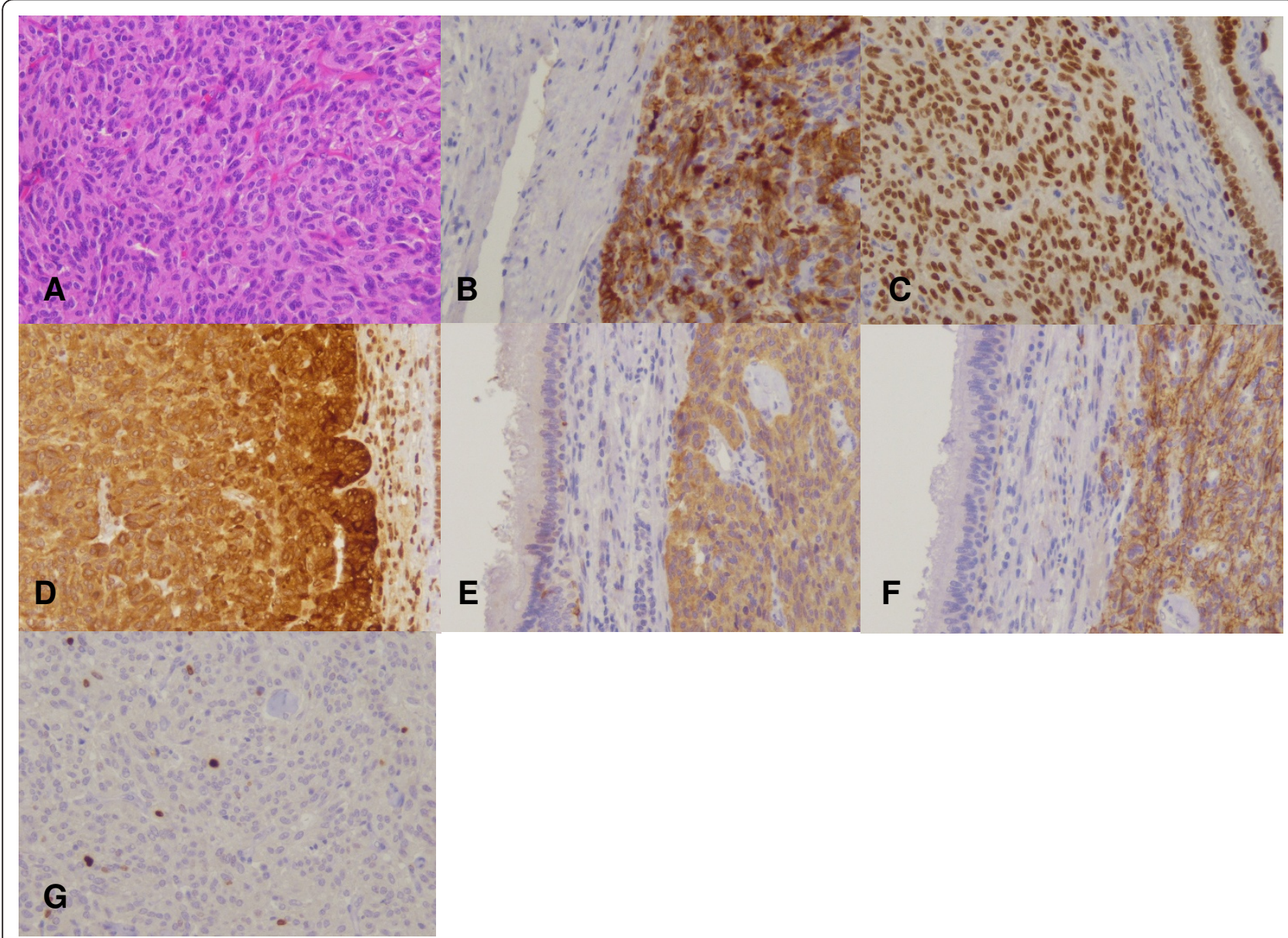

Figure 2 A) HE-staining. B-G) Immunohistochemical stainings. B) Cytoplasmatic expression of CK7. C) Nuclear expression of TTF1. D) Cytoplasmatic expression of chromogranin A. E) Cytoplasmatic expression of synaptophysin. F) Plasma membrane associated expression of CD56. G) Ki-67 labelling index of approximately $5 \%$. 
which are larger than $5 \mathrm{~cm}$ with less than 2 mitoses per 10 high power fields and without necrosis. A minority of carcinoids show an atypical appearance with 2-10 mitoses per 10 high power fields, necrosis and they tend to be more aggressive than typical carcinoids. They also show a higher probability to metastasize, to recur and have a worse outcome and prognosis. These are referred to as atypical carcinoids (ACs) [14-16]. The division of neuroendocrine tumors into different subgroups is nowadays based on the WHO classification of 2004 [16]. Other systems like the embryogenetic classification proposed by Wiliams and Sandler in 1963, which differentiated between carcinoids of the foregut (lung, stomach, duodenum, pancreas, upper jejunum), midgut (lower jejunum, ileum, appendix, caecum) and hindgut (colon, rectum), were too inaccurate and therefore could not prevail [17]. 75-90\% of all bronchopulmonary carcinoids are localized central, $10-25 \%$ peripheral $[18,19]$. $70-90 \%$ are identified as typical and $10-30 \%$ as atypical carcinoids $[8,20]$. TCs are primarily found central and show nodal involvement in 3-20\%, whereas ACs are mostly localized in the periphery of the tracheobronchial tree and show nodal involvement in $48-75 \%[8,21]$. ACs are more often associated with smoking than TCs (62-80\%). In this regard, a correlation between typical carcinoid histology and smoking is not very likely $[6,8,22,23]$. The combination of tumor size and mean nuclear area can be used to predict the presence or absence of regional lymph node metastases in $80 \%$ and $94 \%$ of all cases, respectively [24]. At the time of diagnosis, ACs usually present at a more advanced stage than typical ones. Therefore, an accurate histological diagnosis is essential for further treatment [25]. Mineo et al. published in 2005 that ACs have a higher probability for developing micrometastases, thus explaining the more aggressive clinical behavior. Nodal micrometastases do not correlate with tumor size and stage, implying that even small tumors located in the periphery of the tracheobronchial tree may metastasize. Immunohistochemical detection of micrometastases by using chromoganin A and cytokeratin as markers can help to identify patients with a high risk of recurrence, allowing a more accurate staging [26]. Atypical and typical carcinoid tumors are characterized by a frequent deletion of $11 \mathrm{q}$ material including the MEN1 gene locus. Losses of $10 \mathrm{q}$ and $13 \mathrm{q}$ sequences are more often associated with atypical than with typical carcinoids, making further cytogenetic differentiation possible and probably explaining the more aggressive behavior of ACs [27].

TTF1 is a transcription factor with a molecular weight of $38 \mathrm{kDa}$, which plays an important role in lung morphogenesis and the expression of surfactant factor. It is considered as a dependable marker in distinguishing between primary and metastatic lung adenocarcinomas and can also be helpful in discerning pulmonary neuroendocrine tumors from gastrointestinal ones. The diagnostic value seems to depend on the used antibody clone [28-30]. According to the literature, the expression rate in adenocarcinomas of the lung varies between 7392\% [31-34]. The described expression rate of TTF1 in bronchopulmonary carcinoids also shows a high variability. Rugge et al. and Sturm et al. were not able to detect TTF1-expression in either TCs or ACs. Furthermore, Sturm et al. showed a positive TTF1-expression in $85.5 \%$ and $49 \%$ of all studied SCLCs and LCNECs, respectively. According to the authors, this could imply that carcinoids derive from different stem cells than SCLCs and non-SCLCs including LCNECs $[35,36]$. In this context it is worth mentioning a study published by Sampietro et al., which revealed no relation between carcinoids and small-cell lung carcinomas in gene product immunophenotyping. The authors pointed out that ACs and LCNECs should not be construed as intermediate forms of these two tumor entities [37]. Folpe et al. were able to detect TTF1 in 35\% of all cases in TCs, in $100 \%$ in ACs, in $75 \%$ in LCNECs and in $95 \%$ in SCLCs. The authors also concluded that these results suggest a common cell line origin of SCLCs and TCs [38]. Du et al. described that TTF1 is expressed by neuroendocrine cell hyperplasia in $72.7 \%$, by TCs in $27.8 \%$, by ACs in $29.4 \%$ and by LCNECs in $37.5 \%$ of all cases. They also demonstrated that extrapulmonary neuroendocrine tumors are negative for TTF1, rating it to be $100 \%$ specific but not very sensitive for bronchopulmonary carcinoids and possibly also LCNECs [39]. The predominance of TTF1 in carcinoids of bronchopulmonary origin was confirmed by other studies [40-42]. In contrast to these and other publications, Cai et al. gave an account of positive TTF1-expression in $69 \%$ of their studied carcinoid cases, all tumors except one were TCs [40]. In addition, immunohistochemical detection of Mib1 and $\mathrm{Bcl} 2$ can be useful to differentiate between recurrent and non-recurrent bronchopulmonary carcinoid tumors [35]. The expression of CDX2 and PDX1 is highly specific for identifying neuroendocrine tumors of intestinal origin, since bronchopulmonary carcinoids seem to be negative for these two markers. CK7 is predominantly found in adenocarcinomas of the lung. It is also expressed by $63 \%$ of bronchopulmonary carcinoid tumors and by $11 \%$ of gastrointestinal carcinoids. CK20 is mainly found in adenocarcinomas of the gastrointestinal tract, but not in bronchopulmonary carcinoid tumors. Together with NESP-55, these mentioned markers can help to discriminate between neuroendocrine tumors or adenocarcinomas of pulmonary and such of extrapulmonary origin [34,40-43]. Chromoganin A $(\mathrm{CgA})$ and synaptophysin are commonly used neuroendocrine markers in immunohistochemical analysis [44]. 
Overdiagnosis of typical carcinoid tumors of the lung as SCLCs has been reported previously $[11,12]$. In our case report, the first diagnosis was metastasis of prostate cancer. After initial immunohistochemical stainings and due to the therein reported expression of TTF1, CK7 and the lack of CK20, this diagnosis was changed to primary adenocarcinoma of the lung. Further immunohistochemical stainings were performed. In consideration of the slow tumor progression, the low Ki-67 labelling index and the expression of CgA and synaptophysin, the diagnosis was ultimately changed to TC. Up to this time, we had already conducted a lobectomy to treat the previously suspected adenocarcinoma. As Pelosi et al. stated, careful evaluation of hematoxylin and eosin sections, together with the Ki-67 labelling index, remains the most important tool in discriminating between carcinoids and SCLCs. An index below 20\% is typical for carcinoid tumors, whereas an index above $50 \%$ is usually found in SCLCs.

GnrH receptors and the associated Raf-1/MEK/ERK-1/ 2-pathway are potential targets for analogs in cancer treatment. Activation of the Raf-1/MEK/ERK-1/2-pathway by leflunomide and teriflunomide can inhibit proliferation and growth of BON carcinoid cells in vitro and in vivo and also decrease expression of neuroendocrine markers in both BON and H727 carcinoid cells [45]. Similar effects have been reported for estradiol, ZM336372 and tautomycin [46-50]. Kidd et al. detected GnrH receptor expression in H720, but not in H727 cells and GHRH receptor expression in H727, but not in H720 cells. According to their results for $\mathrm{H} 720$ cells, GnrH +doxorubicin conjugate is a more effective proliferation inhibitor in vitro than doxorubicin alone. In H727 cells, this difference was not observed. Furthermore, GHRH receptor antagonists have an antiproliferative effect in H727 but not in H720 cells [51]. The signaling mechanisms of $\mathrm{GnrH}$ receptors differ significantly from cell type to cell type. For example, signaling in COS7 cells is not dependent on PKC. Since GnrH receptor expression has not been studied in larger patient collectives with carcinoid tumor disease, this raises the question whether there is an association with the above mentioned Raf- 1 / MEK/ERK-1/2-pathway and if its activation is dependent on $\mathrm{GnrH}$ receptors [52]. If there is such a context, the effects of agonists like leuprolide as a GnrH receptor agonists may become of interest. Although we could not detect $\mathrm{GnrH}$-receptors in the examined specimen, there may be individual differences in expression. In this regard, GnrH receptor profiles in TCs and ACs should be scrutinized. Further investigations could lead to new therapeutical options in the treatment of TCs and especially ACs, since the $\mathrm{GnrH}$ receptor has been described as located on the latter [51]. Clinically tested and approved drugs such as leuprolide could come to use.
According to an analysis of eight studies by Gustafsson et al., approximately $58 \%$ of all patients show unspecific symptoms: cough in $32 \%$, hemoptysis in $26 \%$, pneumonia in $24 \%$ of all cases and, to a lesser extent, fever, dyspnoe and chest pain. A carcinoid syndrome occurs seldomly in approximately 1-3\% [53]. Long term obstruction typical for centrally localized tumors can cause multiple bronchiectases in 19\% of all patients [22]. Young and adult patients should undergo further examination if they show long-standing pulmonary symptoms without any response to drug therapy $[54,55]$. To date there is no laboratory test available that could always detect a carcinoid reliably. Several serum markers are used. CgA is a maker of carcinoids in general with a high sensitivity (85.7\%) and specificity (67.9\%), although it can also be detected in SCLCs depending on the clinical stage $[56,57]$. The elevation of CgA can indicate the recurrence of radically operated midgut carcinoid tumors in $85 \%$ of all cases. The measurement of CgA can be recommended for the continuous surveillance of carcinoid patients $[57,58]$. However, CgA is also known to be false positive in some cases, for example in patients with multiple myeloma, renal impairment, atrophic gastritis or proton pump inhibitor therapy [59]. The measurement of 5-HIAA and, according to the clinical symptoms, of ACTH, MSH, GH etc. is only useful if a carcinoid syndrome is suspected. Various diagnostic methods are used in combination. Only $75 \%$ of all patients show a suspicious chest X-ray. Despite a lack of sensitivity and specificity, high resolution CT scans of the abdomen and thorax are used most commonly for an initial localization of the tumor. Carcinoid tumors are known to be highly vascularized and may show a strong contrast agent enhancement. MRI can provide additional information. ${ }^{68} \mathrm{Ga}$-DOTA-peptide PET/CT scans are currently the most accurate imaging procedures for the diagnosis of NETs such as bronchial carcinoids with a sensitivity of $97 \%$ and a specificity of $92 \%$. Even the detection of tumors smaller than $1 \mathrm{~cm}$ is possible. According to a study published by Ambrosini et al., ${ }^{68} \mathrm{Ga}$-DOTANOC PET/CT either affected stage or caused a therapy modification in more than $50 \%$ of the NET patients, proving its superiority to conventional imaging [60]. In this context it should be noted that it can be distinguished between endobronchial carcinoid and inflammatory myofibroblastic tumors by combining ${ }^{18}$ F-FDG PET and ${ }^{68}$ Ga-DOTATOC PET/CT [61]. Prior to this new method, somatostatin receptor scintigraphy was used in imaging, which was not very specific for bronchial carcinoids. A recently published study showed that ${ }^{68} \mathrm{Ga}$-DOTANOC PET/CT is superior to ${ }^{111} \mathrm{In}$-pentetreotide in the detection of CUP-NETs, with a localization rate of the primary tumor of $59 \%$ vs. $39 \%$, respectively. The authors concluded that this method 
can play a major role in the management of patients with CUP-NETs [62]. Bronchial carcinoids are known to be highly vascularized. Nevertheless they show a high rate of false negative results in ${ }^{18} \mathrm{~F}$-FDG PET, although solitary cases of carcinoids with high ${ }^{18} \mathrm{~F}$-FDG uptake have been reported [63-65]. Interestingly, combined diagnostic imaging with ${ }^{131}$ I-MIBG and ${ }^{111}$ In-pentetreotide achieved an overall sensitivity of $95 \%$ for localization of carcinoid tumors. However, this approach was not further pursued [66]. According to the current ACCP guidelines, transthoracic needle biopsy, bronchoscopy or even surgical resection are appropriate means of diagnosis for solitary pulmonary nodules of at least 8$10 \mathrm{~mm}$ diameter. VATS, thoracotomy and mediastinoscopy can be used in combination or as sole diagnostic procedures [67]. Endo- and epibronchial ultrasound can also provide further valuable information $[68,69]$. In this regard, it is important to mention that transthoracic fine needle aspiration biopsy bears the risk of nondiagnostic biopsies. It is dependant on many different factors like tumor size or needle diameter $[67,70]$. Also, there are several reports on implantation metastasis caused by fine needle aspiration biopsy. Although FNAB is considered to be a well-established diagnostic procedure, we think the above mentioned limitations and complication threaten the success of any curative therapy and should not be ignored [71]. ${ }^{18} \mathrm{~F}$-FDG PET/CT scan is known to be highly sensitive, yet has its limitations due to a lower specifity. Like the above mentioned FNAB, a negative $\mathrm{PET} / \mathrm{CT}$ scan does not rule out the possiblity of malignancy of a solitary pulmonary nodule and cannot replace surgical resection [70]. Therefore, we did not see the necessity to perform a preoperative PET/CT scan. Since surgical resection is still considered to be the most reliable diagnostic test $[67,70]$, we prefer surgical diagnostic procedures, if they are feasible. Histological analysis with further immunohistochemical differentiation still remains the gold standard in diagnosing bronchopulmonary carcinoid tumors, with markers like TTF1, CK7, CK20, chromogranin A, synaptophysin and Ki-67 being used routinely.

Surgical resection is still considered to be gold standard in treatment. Nowadays, tissue-sparing procedures become more and more popular, since they show no great difference in long-term survival and a better postoperative quality of life. For this purpose, early diagnosis is essential. The extents of surgical resection and lymph node dissection are still a matter of ongoing debate. Some authors concluded that parenchyma sparing procedures in ACs should be avoided because of a higher recurrence rate $[25,72]$ and are suitable especially for TCs. Others prefer more invasive procedures such as lobectomy in combination with radical lymphadenectomy for any histological kind of carcinoid tumor
$[20,22]$. Endobronchial typical carcinoids with strictly endoluminal growth and small tumor base are reported to be treatable by bronchoscopic resection, showing excellent long term results [69]. Wedge bronchoplasty with large margins should be avoided due to the risk of kinking of the tracheobronchial tree [73]. Some authors pointed out that lymph node dissection should be performed in any patients with atypical carcinoids $[74,75]$, whereas others recommended systematic lymphadenectomy in any carcinoid case $[20,22,24,75]$. Octreotide and chemotherapy are normally used if a carcinoid syndrome or metastases are present. Kaplan et al. even recommended postoperative radiochemotherapy for patients with atypical carcinoids at stage I, reasoning it with higher locoregional failure and distant metastasis rates as compared to patients with typical carcinoids [76]. According to the ACCP guidelines, there is level 2 $\mathrm{C}$ evidence for a conservative and observant approach in case of a new diagnosed pulmonary tumor mass without growth in the last 2 years. However, this strategy is not used very often in practice, because tumors greater than $1.5 \mathrm{~cm}$ in diameter show high potential for malignancy [67]. This approach should therefore be used with caution. Even after radical resection, distant metastases can occur in $8 \%$ of all TC cases and are associated with a worsening of prognosis.

The 10-year survival rate for typical carcinoids ranges from $82 \%$ to $93 \%$, for atypical carcinoids from $56 \%$ to $64 \%[8,69,72,75]$. Modlin et al. described a 5 -year survival rate of $73,5 \%$ for all stages [6]. The various forms of surgical resection techniques used nowadays normally show excellent long-term results. Histology, evidence of invasive growth, nodal status and the presence or absence of distant metastases were identified as the most important prognostic factors for long term survival $[6,7,26,72,75]$. At the time of diagnosis, ACs usually show a more advanced stage than TCs. According to a recently published study, nodal invasion in TCs has no influence on prognosis [9]. In contrast, Martini et al. reported in 1994 that long term survival is independent of lymph node metastases for both TCs and ACs and that recurrence seems to depend more on cell type than nodal status. However, this study only consisted of 25 patients [77]. In case of metastatic disease, TCs may show a similar clinical course like ACs. If the metastases are not resectable, the disease is considered to be incurable $[53,78,79]$.

\section{Conclusion}

Misdiagnosis of bronchopulmonary carcinoid tumors with surgical overtreatment can cause serious consequences for the patient like intra- and postoperative complications with further possible serious limitations of lung function. The use of several immunohistochemical 
markers and careful evaluation of hematoxylin and eosin sections together with the Ki-67 labelling index are important tools in discriminating between carcinoids and other bronchopulmonary carcinomas. Simultaneously, the pre-operative progression of the disease should be considered before defining the extent of initial surgical resection. In case of metastatic disease, TCs may show a similar clinical course like ACs and a significant worsening of prognosis. Therefore, we think that even small TCs which are considered as "stable disease" like our reported case should be resected. Also, a 10-year follow up is recommended.

GnrH receptors and the associated Raf-1/MEK/ERK-1/ 2-pathway are potential targets for analogs in cancer treatment. Activation of the above mentioned pathway can inhibit proliferation and growth of various carcinoid cell types. The typical carcinoid tumor described in our case report showed almost no progression in 5 years. The patient suffered from prostate cancer 4 years ago and was treated with TUR-P, radiation therapy and the application of leuprolide. We suspected a correlation between the lack of tumor growth, application of leuprolide and the Raf-1/MEK/ERK-1/2-pathway. Therefore, we examined GnrH receptor status in the examined specimen. Although we could not detect GnrH-receptors in the examined specimen, there may be individual differences in expression. In this regard, GnrH receptor profiles in TCs and ACs should be scrutinized. Further investigations could lead to new therapeutical options in the treatment of TCs and especially ACs, since the GnrH receptor has already been described on the latter. Clinically tested and approved drugs such as leuprolide could come to use.

\section{Consent}

Written informed consent was obtained from the patient for publication of this Case report and any accompanying images. A copy of the written consent is available for review by the Editor-in-Chief of this journal.

\section{List of abbreviations}

TCs: typical carcinoid tumors; ACs: atypical carcinoid tumors; CgA Chromogranin A; SCLC: small cell lung carcinoma; LCNECs: large cell neuroendocrine carcinomas.

\section{Author details \\ ${ }^{1}$ Department of General, Visceral, Vascular and Thoracic Surgery, Hospital of Düren. ${ }^{2}$ Department of Internal Medicine II, University of Gießen Lung Center, Gießen. ${ }^{3}$ Department of Diagnostic and Interventional Radiology, Hospital of Düren. ${ }^{4}$ Department of Heamatology and Internal Oncology, Hospital of Düren. ${ }^{5}$ The Institute of Pathology, Hospital of Düren.}

\section{Authors' contributions}

ID: preparation and drafting of the manuscript, literature research; $\mathrm{SH}$ : editing of the manuscript; AK: editing of the manuscript; BK: immunohistochemical staining and examination of the specimen, editing of the manuscript; MF: editing of the manuscript; $\mathrm{HJ}$ : editing of the manuscript. All authors read and approved the final manuscript.

\section{Competing interests}

The authors declare that they have no competing interests.

Received: 24 October 2011 Accepted: 23 January 2012

Published: 23 January 2012

\section{References}

1. Laennec RTH: Traite de l'auscultation mediate et des maladies des poumons et du coer. Paris: J.S. Chaudé 1831.

2. Mueller $\mathrm{H}$ : Zur Entstehungsgeschichte der Bronchialerweiterungen. MD thesis University of Halle, Faculty of Medicine; 1882.

3. Lubarsch O: Über den primären Krebs des lleums nebst Bemerkungen über das gleichzeitige Vorkommen von Krebs und Tuberkulose. Virchows Arch Pathol Anat Physiol Klin Med 1888, 111:280-317.

4. Oberndorfer S: Karzinoide Tumoren des Dünndarms. Frankf Z Pathol 1907, 1:426-430.

5. Maggard MA, O'Connell JB, Ko CY: Updated population-based review of carcinoid tumors. Ann Surg 2004, 240:117-22.

6. Modlin IM, Lye KD, Kidd M: A 5-decade analysis of 13,715 carcinoid tumors. Cancer 2003, 97:934-59.

7. Yao JC, Hassan M, Phan A, Dagohoy C, Leary C, Mares JE, Abdalla EK, Fleming JB, Vauthey JN, Rashid A, Evans DB: One hundred years after "carcinoid": epidemiology of and prognostic factors for neuroendocrine tumors in 35,825 cases in the United States. J Clin Oncol 2008, 26:3063-72.

8. Fink G, Krelbaum T, Yellin A, Bendayan D, Saute M, Glazer M, Kramer MR: Pulmonary carcinoid: presentation, diagnosis, and outcome in 142 cases in Israel and review of 640 cases from the literature. Chest 2001, 119:1647-51

9. García-Yuste M, Matilla JM, Cueto A, Paniagua JM, Ramos G, Cañizares MA, Muguruza I: Typical and atypical carcinoid tumours: analysis of the experience of the Spanish Multi-centric Study of Neuroendocrine Tumours of the Lung. Eur J Cardiothorac Surg 2007, 31:192-7.

10. Quaedvlieg PF, Visser O, Lamers CB, Janssen-Heijen ML, Taal BG Epidemiology and survival in patients with carcinoid disease in The Netherlands. An epidemiological study with 2391 patients. Ann Oncol 2001, 12:1295-300.

11. Pelosi G, Rodriguez J, Viale G, Rosai J: Typical and atypical pulmonary carcinoid tumor overdiagnosed as small-cell carcinoma on biopsy specimens: a major pitfall in the management of lung cancer patients. Am J Surg Pathol 2005, 29:179-87.

12. Valente M, Catena L, Milione M, Pusceddu S, Formisano B, Bajetta E: Common Diagnostic Challenges in the Histopathologic Diagnosis of Neuroendocrine Lung Tumors: A Case Report. Case Rep Oncol 2010, 3:202-207.

13. Gould VE, Linnoila RI, Memoli VA, Warren WH: Neuroendocrine components of the bronchopulmonary tract: hyperplasias, dysplasias, and neoplasms. Lab Invest 1983, 49:519-37.

14. Arrigoni MG, Woolner LB, Bernatz PE: Atypical carcinoid tumors of the lung. J Thorac Cardiovasc Surg 1972, 64:413-21.

15. Hamperl H: Über gutartige Bronchialtumoren (Cylindrome und Carcinoide). Virchows Arch Pathol Anat Physiol Klin Med 1937, 300:46-88.

16. Travis WD, Brambilla E, Müller-Hermelink HK, Harris CC: Pathology and genetics of tumours of the lung, pleura, thymus and heart. In World Health Organization classification of tumours. Edited by: Kleihues P, Sobin LH. Lyon: IARC Press; 2004:

17. Williams ED, Sandler M: The classification of carcinoid tumours. Lancet 1963, 1:238-9.

18. Alp M, Uçanok K, Doğan R, Kaya S, Cetin G, Unlü M, Yorulmaz F, Moldibi B: Surgical treatment of bronchial adenomas: results of 29 cases and review of the literature. Thorac Cardiovasc Surg 1987, 35:290-4.

19. Rekhtman N: Neuroendocrine tumors of the lung: an update. Arch Pathol Lab Med 2010, 134:1628-38.

20. Davini F, Gonfiotti A, Comin C, Caldarella A, Mannini F, Janni A: Typical and atypical carcinoid tumours: 20-year experience with 89 patients. $J$ Cardiovasc Surg (Torino) 2009, 50:807-11. 
21. Marty-Ané CH, Costes V, Pujol JL, Alauzen M, Baldet P, Mary H: Carcinoid tumors of the lung: do atypical features require aggressive management? Ann Thorac Surg 1995, 59:78-83.

22. Daddi N, Ferolla P, Urbani M, Semeraro A, Avenia N, Ribacchi R, Puma F, Daddi G: Surgical treatment of neuroendocrine tumors of the lung. Eur J Cardiothorac Surg 2004, 26:813-7.

23. Valli M, Fabris GA, Dewar A, Hornall D, Sheppard MN: Atypical carcinoid tumour of the lung: a study of 33 cases with prognostic features. Histopathology 1994, 24:363-9.

24. Thunnissen FB, Van Eijk J, Baak JP, Schipper NW, Uyterlinde AM, Breederveld RS, Meijer S: Bronchopulmonary carcinoids and regional lymph node metastases. A quantitative pathologic investigation. Am J Pathol 1988, 132:119-22.

25. Ferguson MK, Landreneau RJ, Hazelrigg SR, Altorki NK, Naunheim KS, Zwischenberger JB, Kent M, Yim AP: Long-term outcome after resection for bronchial carcinoid tumors. Eur J Cardiothorac Surg 2000, 18:156-61.

26. Mineo TC, Guggino G, Mineo D, Vanni G, Ambrogi V: Relevance of lymph node micrometastases in radically resected endobronchial carcinoid tumors. Ann Thorac Surg 2005, 80:428-32.

27. Walch AK, Zitzelsberger HF, Aubele MM, Mattis AE, Bauchinger M, Candidus S, Präuer HW, Werner M, Höfler H: Typical and atypical carcinoid tumors of the lung are characterized by $11 \mathrm{q}$ deletions as detected by comparative genomic hybridization. Am J Pathol 1998, 153:1089-98.

28. Compérat $E$, Zhang F, Perrotin C, Molina T, Magdeleinat $P$, Marmey $B$, Régnard JF, Audouin J, Camilleri-Broët S: Variable sensitivity and specificity of TTF-1 antibodies in lung metastatic adenocarcinoma of colorectal origin. Mod Pathol 2005, 18:1371-6.

29. La Rosa S, Chiaravalli AM, Placidi C, Papanikolaou N, Cerati M, Capella C: TTF1 expression in normal lung neuroendocrine cells and related tumors: immunohistochemical study comparing two different monoclonal antibodies. Virchows Arch 2010, 457:497-507.

30. Matoso A, Singh K, Jacob R, Greaves WO, Tavares R, Noble L, Resnick MB, Delellis RA, Wang $L$ : Comparison of thyroid transcription factor-1 expression by 2 monoclonal antibodies in pulmonary and nonpulmonary primary tumors. Appl Immunohistochem Mol Morphol 2010, 18:142-9.

31. Bakir $\mathrm{K}$, Koçer NE, Deniz H, Güldür ME: TTF-1 and surfactant-B as coadjuvants in the diagnosis of lung adenocarcinoma and pleural mesothelioma. Ann Diagn Pathol 2004, 8:337-41.

32. Hecht $J L$, Pinkus $J L$, Weinstein $L$, Pinkus GS: The value of thyroid transcription factor- 1 in cytologic preparations as a marker for metastatic adenocarcinoma of lung origin. Am J Clin Pathol 2001, 116:483-8.

33. Moldvay J, Jackel M, Bogos K, Soltész I, Agócs L, Kovács G, Schaff Z: The role of TTF-1 in differentiating primary and metastatic lung adenocarcinomas. Pathol Oncol Res 2004, 10:85-8.

34. Su YC, Hsu YC, Chai CY: Role of TTF-1, CK20, and CK7 immunohistochemistry for diagnosis of primary and secondary lung adenocarcinoma. Kaohsiung J Med Sci 2006, 22:14-9.

35. Rugge M, Fassan M, Clemente R, Rizzardi G, Giacomelli L, Pennelli G, Mescoli C, Segat D, Rea F: Bronchopulmonary carcinoid: phenotype and long-term outcome in a single-institution series of Italian patients. Clin Cancer Res 2008, 14:149-54.

36. Sturm N, Rossi G, Lantuejoul S, Papotti M, Frachon S, Claraz C, Brichon PY, Brambilla C, Brambilla E: Expression of thyroid transcription factor-1 in the spectrum of neuroendocrine cell lung proliferations with special interest in carcinoids. Hum Pathol 2002, 33:175-82.

37. Sampietro G, Tomasic G, Collini P, Biganzoli E, Boracchi P, Bidoli P, Pilotti S: Gene product immunophenotyping of neuroendocrine lung tumors. No linking evidence between carcinoids and small-cell lung carcinomas suggested by multivariate statistical analysis. Appl Immunohistochem Mol Morphol 2000, 8:49-56.

38. Folpe AL, Gown AM, Lamps LW, Garcia R, Dail DH, Zarbo RJ, Schmidt RA: Thyroid transcription factor-1: immunohistochemical evaluation in pulmonary neuroendocrine tumors. Mod Pathol 1999, 12:5-8.

39. Du EZ, Goldstraw P, Zacharias J, Tiffet O, Craig PJ, Nicholson AG, Weidner N, Yi ES: TTF-1 expression is specific for lung primary in typical and atypical carcinoids: TTF-1-positive carcinoids are predominantly in peripheral location. Hum Pathol 2004, 35:825-31.

40. Cai YC, Banner B, Glickman J, Odze RD: Cytokeratin 7 and 20 and thyroid transcription factor 1 can help distinguish pulmonary from gastrointestinal carcinoid and pancreatic endocrine tumors. Hum Pathol 2001, 32:1087-93.

41. Lin X, Saad RS, Luckasevic TM, Silverman JF, Liu Y: Diagnostic value of CDX-2 and TTF-1 expressions in separating metastatic neuroendocrine neoplasms of unknown origin. Appl Immunohistochem Mol Morphol 2007, 15:407-14.

42. Srivastava A, Hornick JL: Immunohistochemical staining for CDX-2, PDX-1, NESP-55, and TTF-1 can help distinguish gastrointestinal carcinoid tumors from pancreatic endocrine and pulmonary carcinoid tumors. Am I Surg Pathol 2009, 33:626-32.

43. Chu P, Wu E, Weiss LM: Cytokeratin 7 and cytokeratin 20 expression in epithelial neoplasms: a survey of 435 cases. Mod Pathol 2000, 13:962-72.

44. Al-Khafaji B, Noffsinger AE, Miller MA, DeVoe G, Stemmermann GN, Fenoglio-Preiser C: Immunohistologic analysis of gastrointestinal and pulmonary carcinoid tumors. Human pathology 1998, 29:992-999.

45. Cook MR, Pinchot SN, Jaskula-Sztul R, Luo J, Kunnimalaiyaan M, Chen H: Identification of a novel Raf-1 pathway activator that inhibits gastrointestinal carcinoid cell growth. Mol Cancer Ther 2010, 9:429-37.

46. Greenblatt DY, Kunnimalaiyaan M, Chen H: Raf-1 activation in gastrointestinal carcinoid cells decreases tumor cell adhesion. Am J Surg 2007, 193:331-5.

47. Kunnimalaiyaan $\mathrm{M}$, Chen $\mathrm{H}$ : The Raf-1 pathway: a molecular target for treatment of select neuroendocrine tumors? Anticancer Drugs 2006, 17:139-42.

48. Kunnimalaiyaan $\mathrm{M}$, Ndiaye $\mathrm{M}, \mathrm{Chen} \mathrm{H}$ : Neuroendocrine tumor cell growth inhibition by ZM336372 through alterations in multiple signaling pathways. Surgery 2007, 142:959-64

49. Pinchot SN, Adler JT, Luo Y, Ju J, Li W, Shen B, Kunnimalaiyaan M, Chen H: Tautomycin suppresses growth and neuroendocrine hormone markers in carcinoid cells through activation of the Raf-1 pathway. Am J Surg 2009, 197:313-9.

50. Van Gompel JJ, Kunnimalaiyaan M, Holen K, Chen H: ZM336372, a Raf-1 activator, suppresses growth and neuroendocrine hormone levels in carcinoid tumor cells. Mol Cancer Ther 2005, 4:910-7.

51. Kidd M, Schally AV, Pfragner R, Malfertheiner MV, Modlin IM: Inhibition of proliferation of small intestinal and bronchopulmonary neuroendocrine cell lines by using peptide analogs targeting receptors. Cancer 2008, 112:1404-14

52. Kraus $S$, Naor Z, Seger R: Intracellular signaling pathways mediated by the gonadotropin-releasing hormone $(\mathrm{GnRH})$ receptor. Arch Med Res 2001, 32:499-509.

53. Gustafsson BI, Kidd M, Chan A, Malfertheiner MV, Modlin IM: Bronchopulmonary neuroendocrine tumors. Cancer 2008, 113:5-21.

54. Andersen JB, Mortensen J, Damgaard K, Skov M, Sparup J, Petersen BL, Rechnitzer C, Borgwardt L: Fourteen-year-old girl with endobronchial carcinoid tumour presenting with asthma and lobar emphysema. Clin Respir J 2010, 4:120-4.

55. Emeryk J, Czekajska-Chehab E, Korobowicz E, Korbel M, Wegrzyn-Szkutnik I, Milanowski J: Bronchial carcinoid in a 39-year-old man treated for bronchial asthma: a case report. Cases J 2008, 2:7414.

56. Bajetta E, Ferrari L, Martinetti A, Celio L, Procopio G, Artale S, Zilembo N, Di Bartolomeo M, Seregni E, Bombardieri E: Chromogranin A, neuron specific enolase, carcinoembryonic antigen, and hydroxyindole acetic acid evaluation in patients with neuroendocrine tumors. Cancer 1999, 86:858-65.

57. Seregni E, Ferrari L, Bajetta E, Martinetti A, Bombardieri E: Clinical significance of blood chromogranin A measurement in neuroendocrine tumours. Ann Oncol 2001, 12(Suppl 2):S69-72.

58. Welin S, Stridsberg M, Cunningham J, Granberg D, Skogseid B, Oberg K, Eriksson B, Janson ET: Elevated plasma chromogranin A is the first indication of recurrence in radically operated midgut carcinoid tumors. Neuroendocrinology 2009, 89:302-7.

59. Nobels FR, Kwekkeboom DJ, Coopmans W, Schoenmakers CH, Lindemans J, De Herder WW, Krenning EP, Bouillon R, Lamberts SW: Chromogranin A as serum marker for neuroendocrine neoplasia: comparison with neuronspecific enolase and the alpha-subunit of glycoprotein hormones. J Clin Endocrinol Metab 1997, 82:2622-8.

60. Ambrosini V, Campana D, Bodei L, Nanni C, Castellucci P, Allegri V, Montini GC, Tomassetti P, Paganelli G, Fanti S: 68Ga-DOTANOC PET/CT clinical impact in patients with neuroendocrine tumors. J Nucl Med 2010, 51:669-673. 
61. Jindal T, Kumar A, Dutta R, Kumar R: Combination of (18)-FDG and (68)GaDOTATOC PET-CT to differentiate endobronchial carcinoids and inflammatory myofibroblastic tumors. J Postgrad Med 2009, 55:272-4.

62. Prasad V, Ambrosini V, Hommann M, Hoersch D, Fanti S, Baum RP: Detection of unknown primary neuroendocrine tumours (CUP-NET) using (68)Ga-DOTA-NOC receptor PET/CT. Eur J Nucl Med Mol Imaging 2010, 37:67-77.

63. Chong S, Lee KS, Chung MJ, Han J, Kwon OJ, Kim TS: Neuroendocrine tumors of the lung: clinical, pathologic, and imaging findings. Radiographics 2006, 26:41-58.

64. Jadvar H, Segall GM: False-negative fluorine-18-FDG PET in metastatic carcinoid. J Nucl Med 1997, 38:1382-3.

65. Suemitsu R, Maruyama R, Nishiyama K, Okamoto T, Wataya H, Seto T, Ichinose $Y$ : Pulmonary typical carcinoid tumor and liver metastasis with hypermetabolism on 18-fluorodeoxyglucose PET: a case report. Ann Thorac Cardiovasc Surg 2008, 14:109-11.

66. Taal BG, Hoefnagel CA, Valdés Olmos RA, Boot H: Combined diagnostic imaging with 1311-metaiodobenzylguanidine and $111 \mathrm{ln}$-pentetreotide in carcinoid tumours. Eur J Cancer 1996, 32A:1924-32.

67. Gould MK, Fletcher J, lannettoni MD, Lynch WR, Midthun DE, Naidich DP, Ost DE: Evaluation of patients with pulmonary nodules: when is it lung cancer?: ACCP evidence-based clinical practice guidelines (2nd edition). Chest 2007, 132(Suppl 3):108S-130S.

68. Belak J, Kudlac M, Zak V, Cavarga I, Kocan P, Böör A, Stebnicky M, Somos A, Tkacova R: Surgical management of bronchopulmonary carcinoid tumors: experience over 8 years and review of the literature. Tumori 2010, 96:84-9.

69. Fuks L, Fruchter O, Amital A, Fox BD, Abdel Rahman N, Kramer MR: Longterm follow-up of flexible bronchoscopic treatment for bronchial carcinoids with curative intent. Diagn Ther Endosc 2009, 2009:782961.

70. Wahidi MM, Govert JA, Goudar RK, Gould MK, McCrory DC, American College of Chest Physicians: Evidence for the treatment of patients with pulmonary nodules: when is it lung cancer?: ACCP evidence-based clinical practice guidelines (2nd edition). Chest 2007, 132(3 Suppl):94S-107S.

71. Yoshikawa T, Yoshida J, Nishimura M, Yokose T, Nishiwaki Y, Nagai K: Lung cancer implantation in the chest wall following percutaneous fine needle aspiration biopsy. Jpn J Clin Oncol 2000, 30:450-2.

72. Mezzetti M, Raveglia F, Panigalli T, Giuliani L, Lo Giudice F, Meda S, Conforti S: Assessment of outcomes in typical and atypical carcinoids according to latest WHO classification. Ann Thorac Surg 2003, 76:1838-42

73. Kurul IC, Topçu S, Taştepe I, Yazici U, Altinok T, Cetin G: Surgery in bronchial carcinoids: experience with 83 patients. Eur J Cardiothorac Surg 2002, 21:883-7.

74. Cardillo G, Sera F, Di Martino M, Graziano P, Giunti R, Carbone L, Facciolo F, Martelli M: Bronchial carcinoid tumors: nodal status and long-term survival after resection. Ann Thorac Surg 2004, 77:1781-5.

75. Rea F, Rizzardi G, Zuin A, Marulli G, Nicotra S, Bulf R, Schiavon M, Sartori F: Outcome and surgical strategy in bronchial carcinoid tumors: single institution experience with 252 patients. Eur J Cardiothorac Surg 2007, 31:186-91.

76. Kaplan B, Stevens CW, Allen P, Liao Z, Komaki R: Outcomes and patterns of failure in bronchial carcinoid tumors. Int J Radiat Oncol Biol Phys 2003, 55:125-31.

77. Martini N, Zaman MB, Bains MS, Burt ME, McCormack PM, Rusch WW, Ginsberg RJ: Treatment and prognosis in bronchial carcinoids involving regional lymph nodes. J Thorac Cardiovasc Surg 1994, 107:1-7.

78. Naalsund A, Rostad H, Strøm EH, Lund MB, Strand TE: Carcinoid lung tumors-incidence, treatment and outcomes: a population-based study. Eur J Cardiothorac Surg 2011, 39:565-9.

79. Warren WH, Gould VE: Long-term follow-up of classical bronchial carcinoid tumors. Clinicopathologic observations. Scand J Thorac Cardiovasc Surg 1990, 24:125-30.

doi:10.1186/1477-7819-10-19

Cite this article as: Demirci et al:: Overdiagnosis of a typical carcinoid tumor as an adenocarcinoma of the lung: a case report and review of the literature. World Journal of Surgical Oncology 2012 10:19.

\section{Submit your next manuscript to BioMed Central and take full advantage of:}

- Convenient online submission

- Thorough peer review

- No space constraints or color figure charges

- Immediate publication on acceptance

- Inclusion in PubMed, CAS, Scopus and Google Scholar

- Research which is freely available for redistribution

Submit your manuscript at www.biomedcentral.com/submit
Biomed Central 